\title{
DEVELOPMENT OF INSTRUCTIONAL MATERIALS WRITING POETRY BASED ON NATURE TOURISM FOR POETRY LEARNING
}

\author{
Galang Prasetyo Aji, Yuni Pratiwi, Nita Widiarti* \\ State University of Malang, Indonesia
}

\section{A R T I C LE INF O}

\section{Keyword:}

teaching materials,

writing poetry,

nature tourism,

learning

\begin{abstract}
A B S T R A C T
Teaching materials is one of the government's alternatives in its efforts to achieve educational goals. Interesting learning process is a learning that uses resources, media, and various other learning support, especially textbooks. Once the importance of the book as a learning resource, it is important for us to develop it, especially the material to write poetry. A teaching material to write poetry will be more interesting for students if the theme is focused and more deeply when writing poetry, so the selection of natural tourism theme is determined so that students more easily in writing and understanding poetry. Creation of a teaching material is intended to make it easier for students to understand about nature-based poetry. This article will discuss the essence of teaching materials, the characteristics of teaching materials, the essence of poetry, the purpose of writing poetry, and learning about writing natural-based poetry as an effort to help understand the poetry of nature.
\end{abstract}

\section{INTRODUCTION}

Teaching materials so far have been provided by the government for learning activities for students and guidebooks for teachers (Suyitno, Susanto, Kamal, \& Fawzi, 2017). Teaching materials provided by the government need to be collaborated to make learning more innovative. Innovation can be done is to create better teaching materials, so that the insight of learners in learning to write poetry more and growing. According to Hamidah \& Siswanto (1995:71), teaching materials are written using the same instructional strategies used in ordinary classroom teaching. Given that the development of teaching materials is an important activity undertaken as a support for student learning, the development of teaching materials should be activated again.

The interesting learning process is a learning that uses resources, media, and various other learning support, especially textbooks. The creation of new innovative poetry writing materials can create a more interesting learning for students and teachers alike. A good teaching material should include (1) instructional (teachers and students), (2) competence to be achieved, (3) supporting information, (4) exercises, (5) instructions/worksheets, and (6) evaluation (Lestari, 2014:3).

Poetry will be more beautiful if the physical structure and inner structure are written in a coherent manner. Writing poetry is an activity can foster a person's imagination. The author tries to express the reality of one's life through the verbal portrait of life, the thoughts, feelings, and the obsessions of reality he expresses (Pratiwi, et al., 2016:1-2). Therefore, the scope of this study is to express the use of teaching materials as a means to facilitate students in understanding about nature tourism.

\section{THE ESSENCE OF TEACHING MATERIALS}

A learning will be created fun if the learning resources used are interesting. Pannen said that teaching materials contain a systematic set of materials used by teachers and learners in learning activities

\footnotetext{
" Corresponding author.

E-mail addresses: galangprasaji@gmail.com (Galang Prasetyo Aji)
}

ISSN : 2597-7385 (Online) - ISLLAC : Journal of Intensive Studies on Language, Literature, Art, and Culture is licensed under Creative Commons Attribution-ShareAlike 4.0 International License (http://creativecommons.org/licenses/BY/4.0/).

35 | ISLLAC : Journal of Intensive Studies on Language, Literature, Art, and Culture 
to create an atmosphere and an interesting environment (Bahtiar, 2015:2). The main learning resources are textbooks or learning materials. The teaching materials comprise a set of learning tools that contain learning materials, methods, constraints, and evaluating events that are designed systematically and appealing in order to achieve the expected learning objectives (Widodo, 2008: 40). For that, teachers need to understand the characteristics of learning that will be submitted so as not wrong in choosing a strategy, interaction, class management, and selection of media or learning materials, and tools evaluation (Siddiq, et al, 2008:19).

Teaching materials are everything that made by educators as a medium in teaching and learning activities. Teaching materials have benefits according to the demand of the curriculum in place of textbooks that tend to be difficult to obtain (Depdiknas, 2008:6). Similarly, Sanjaya (2008:141) said that the teaching materials is everything that the curriculum content that must be mastered by students in accordance with basic competencies in order to achieve the competency standards of each subject in a particular education unit. Teaching materials should be arranged systematically and display the integrity of the competencies that will be mastered by learners in the learning process with the aim of planning and reviewing the implementation of learning (Prastowo, 2013:17). Therefore, teaching materials should be able to provide solutions for the achievement of student competence. Majid (2008:174) states that teaching materials are all forms of material that can be used by teachers as a tool in teaching and learning activities in the classroom. A form of materials used to assist teachers in carrying out teaching and learning activities in the classroom (Ahmadi, et al., 2011: 208).

Based on the description, it can be concluded that the understanding of teaching materials is any form of material that is structured as a tool for learning in the classroom. Teaching materials also serve as a tool for measuring how deep the students understand the material being taught. Therefore, teaching materials is a compulsory material present in the learning process.

\section{DESIGN AND CHARACTERISTICS OF TEACHING MATERIALS}

There are many types of instructional materials designs often encountered in learning, but most often encountered in learning are printed materials. Richards (2002: 521) states that there are three forms of teaching materials, namely (1) printed materials such as textbooks, notebooks, worksheets, or readings, (2) non print teaching materials such as cassettes, audio, video, or material computer-based, and (3) material consisting of both such as self learning materials and teaching materials that exist on the internet. In line with Richard's opinion, Majid (2008: 174) states that the form of teaching materials can be grouped into four, namely (1) print materials, (2) teaching materials with audio, (3) teaching materials audiovisual, and (4) interactive teaching material.

A teaching material, of course, has different characteristics, it can be a hallmark of a teaching material itself. Widodo and Jasmadi divide the teaching material characteristics consisting of five parts, namely self-instructional, self-contained, stand-alone, adaptive, dan user-friendly (Lestari, 2013:2). Characteristics of teaching materials according to Seoane \& Rodriguez (2014: 25-27) there are four, namely (1) the material is designed in concept, (2) diverse formats, teaching materials addressed according to user needs, (3) designed according to context, teaching materials designed by experts and tailored to the user's background, and (4) territorial principle, namely created according to the user's local potential. Based on the description, it can be concluded that the characteristics of teaching materials are as a learning material that contains material conceptualized and adapted to a potential area that can support a fun learning.

\section{THE ESSENCE OF POETRY}

Poetry is a literary work in the form of writing to express a person's idea or idea as a medium for conveying a meaning through language. Poetry is a reflection of strong diversity, teaching us to appreciate the freedom to praise and criticize. Pratiwi, et al., (2016:15) says that the essence of poetry is the poet's spiritualist revelation through creative and multi-interpretative writing language, creating an aesthetic imaginary space of the poet and reader by considering the arrangement of lines and stanzas to create typical typographical or topographical features. Poetry urges us not to impose power in interpreting and to develop non-instructive and less educative responses.

Herbert (2007:200) classifies the form of poetry in two ways. First, the poems are conscious of the form. Secondly, in certain cases, his writings are only able to show the advantages that are regarded as free verse. The most basic thing we can mention about its shape is that it is based on the perception of the listener. From the form of poetry that can be determined the elements contained in it. The element contained in the poetry is basically two elements of the builder, namely extrinsic structure, and intrinsic structure. The structure of poetry deals with the composition of poetry, the subject of each verse, the linkage of each verse, or in other words the poet's thought process (TLC:2). The extrinsic structure of poetry 
relates to forming, while the intrinsic structure is concerned with the content or meaning contained in the text. Waluyo (2010:32) says that there are two structures in poetry, namely the first, intrinsic structure consisting of theme, tone, feeling, and mandate. Second, an extrinsic structure consisting of diction, imagination, concrete word, the figure of speech, verification, and typography in poetry.

Both element of the poetical builder is an important element in writing poetry. Before writing a poem of course we need to pay attention to the theme we will write. The theme that we choose will be a reference that can facilitate us in writing poetry. However, the element of the poetical builder is basically not a benchmark for the author to pour his imagination, this element only aims to provide the essence of poetry literary works that distinguish with other literary works (Teeuw, 2012:127).

\section{POETRY WRITING PROCES}

Writing poetry is an underlying activity in an appreciation of poetry, which produces a poem. Endraswara (2003:220) states that the creation or writing of poetry can be initiated from several processes, namely sensing, contemplation, precipitation, and wordplay. In the process of sensing, conducted activities of observation of an object. Writing poetry involves a lot of senses, especially ears and poetry is highly dependent on the rhythm manipulation we make (Herbert, 2007:200).

Ingermanson and Economy (2010:9) say that writing fiction means developing the writing skill continuously, strategically and tactically in writing a fiction using a talent and perseverance. Writing poetry is part of writing a fiction. Before someone writes poetry fiction, of course, it is necessary to pay close attention to and accurately the writing in order to obtain a beauty and satisfaction in creating a work of fiction. Reading a work of fiction repeatedly will be useful in understanding and enjoying a work of fiction (Stanton, 2007:5).

The important thing that someone must consider before writing is the benefit of the writing itself. An information to be written should inform the other person what he wants to write. According to Ramet (2007:1), what someone needs to do in writing is to spend time on writing. The first thing to remember is the essence of a writer is to write everything that can be done every day. Someone can produce any manuscript according to the desired genre. As an important novice writer is required to believe that the writing they write is important (Eneste, 2009).

According to Sherry \& Schouten (2002:224), poetry is a form of expression that utilizes intuition by exploring what is unknown. The object can be an event, an object, nature, or yourself. The language used in poetry is of course not the same as the language as our daily communication or the more formal and standard scholarly language. The language of poetry is the language of literature, which is essentially richer in connotations or fictional depictions. Jabrohim, et al., (2001:5) states that the language of literature (poetry) is very connotative. The language of poetry not only explains it, but also has an expressive aspect, convey the tone and attitude of the poet, and tend to be personal, the point is that poetry language not only states and explains what is said in poetry, it also evokes the reader's feelings in persuading, influencing attitudes, and ultimately changing the reader's position.

Giovanni Pascoli argues that there is a connection between poetry with various creatures, phenomena, and natural objects, then Pascoli equates that poetry is equated with everything that is pure and beautiful (Ukas, 2010:51). From that interpretation is born with the term of nature poetry. The poets before creating a poem themed nature, first to sensing the natural surroundings in order to find the beauty that exists in nature around the poet (Laeli, et al., 2013:3). Therefore, the poetry of nature is the work of the depiction of nature through words.

The poet who loves nature will be praised by speaking and writing in various forms, such as prose or poetry. According to Boles (1973:2), natural poetry utilizes figure of speech, symbolism, and deceit to set the stage of expression of experience beyond mere description. According to Hartanto (2015:20), nature is a basic image of life, both as a living environment, a daily activity, the background of an event, to various things and physical and non-physical objects that exist the whole universe.

\section{LEARNING POETRY BASED NATURAL TOURISM}

Nature is one tourist attraction that has a variety of functions. Nature as a tourist destination, of course, must be considered by each region because of valuable assets. A natural tourism can be used as a superior owned area. Natural potential owned by each region is certainly not the same, it can be an attraction and characteristic of an area. A love of a region is really needed by someone, especially the younger generation. This is because one needs to realize that the area has a privilege and should be used as a means of good development. The goal is, of course, to make someone have a sense of admiring, loving, and appreciate the potential that exists in the area. 
The scope of tourism development has been formulated by the Minister of Tourism Regulation number 10 of 2016, namely the development of tourism as referred to in clause 7 of Law Number 10 the Year 2009 on tourism includes: (1) tourism industry, (2) tourism destinations, (3) tourism marketing, and (4) tourism institutions. The four pillars need to be done simultaneously, equilibrium, and not a sequential sequence. The learning of thematic tourism has been emphasized in Government Regulation no. 19 of 2005 on National Education Standards CHAPTER III clause 14 paragraph (1) on the National Education Standards states that the curriculum level of junior secondary school / MTs / SMPLB, or other similar forms developed in accordance with the educational unit, the potential regional / local characteristics, social culture of local communities, and learners. The curriculum of elementary and secondary education shall include skills or vocational and local content. Therefore, tourism-themed learning is an obligation to be studied in school.

The learning of writing nature-themed poems for Junior High School students aims to help students understand about nature-themed poems and how to write them. The material chosen must be considered by the teacher, so the selection of the material should be in accordance with the condition of the students of Junior High School. The strategy used is to create an active and communicative learning. Various sources or media should be utilized so that the learning is not lectured by the teacher. At the end of the learning activities, there should be evaluation or assessment, the purpose is to know the competence to be achieved, namely the ability of learners in understanding and the process of writing the poem.

To write a poem with a theme of nature, poet poets have the freedom to choose diction or metaphor according to the poem's perspective. The most important fact in writing poetry on nature is that the results are varied, depending on who or what is being realized, on time, day, season, and on the situation (Ukas, 2010:55). Most natural poems describe the natural beauty of the mountains, the sea, the forest, and others as a form of one's emotions (Boles (1973:3). Thus natural poetry is very good in learning because it will train the mind power, imagination, and creativity of students using diction in describing something related to nature.

\section{CONCLUSIONS}

From the various descriptions previously mentioned, we can give students more understanding of nature. A good understanding, of course, needs to be supported by sources or media that facilitate a learner. Learning resources that can be used one of them is teaching materials because a teaching material is a means of supporting a learning. The learning of writing poetry based on nature tourism aims to hone students' ability and understanding related to nature tourism which is expressed through a series of words of poetry. A simple representation of the elements of the poetry builder in the created material will make it easier for students to understand and write a poem. The selection of appropriate materials, the use of various media variations, and the assessment of the outcomes understand the process of writing poetry based on nature tourism.

\section{REFERENCES}

Ahmadi, I.K, Amri, S, \& Elisah, T. (2011). Strategi Pembelajaran Sekolah Terpadu: Pengaruhnya terhadap Konsep, Mekanisme, dan Proses Pembelajaran Sekolah Swasta dan Negeri (Integrated School Learning Strategy: Influence on Concept, Mechanism, and Learning Process of Private School and Country). Jakarta: Prestasi Pustaka Publisher.

Bahtiar, E.T. (2015). Penulisan Bahan Ajar. Artikel disajikan dalam kegiatan Conference Paper di Bogor (Writing Teaching materials. Articles are presented in the activity Conference Paper in Bogor). Bogor, $\quad$ Oktober 2015. (https://www.researchgate.net/publication/283042709_Penulisan_Bahan_Ajar).

(Online)

Boles, R.J. (1973). Nature Poetry. Kansas: Kansas State Teacher College of Emporia. Journal The Kansas School Naturalist Vol. 20 No. 2.

Depdiknas. (2008). Panduan Pengembangan Bahan Ajar (Guidance on Teaching Materials Development). Jakarta: Departemen Pendidikan Nasional.

Endraswara, S. (2003). Membaca, Menulis, Mengajarkan Sastra (Reading, Writing, Teaching Literature). Yogyakarta: Ikatan Penerbit Indonesia (IKAPI).

Eneste, P. (2009). Proses Kreatif: Mengapa dan Bagaimana Saya Mengarang (Creative Process: Why and How I Author). Jakarta: PT Gramedia.

Hamidah, C.S. \& Siswanto, W. (1995). Perencanaan Pengajaran Bahasa Indonesia (Planning Teaching Bahasa Indonesia). Malang. Depdikbud.

38 | ISLLAC : Journal of Intensive Studies on Language, Literature, Art, and Culture 
Hartanto, W. (2015). Citraan Alam dalam Kumpulan Puisi Refrein di Sudut Dam Karya D. Zawawi Imron (Natural Imagery in a Collection of Poetry in Sudut Dam Creation D. Zawawi Imron). Yogyakarta: Universitas Negeri Yogyakarta. Skripsi tidak diterbitkan.

Herbert, W.N. (2007). What is Form? At Steven Earnshaw (eds) The Handbook of Creative Writing. Edinburgh: Edinburgh University Press.

Ingermanson, R. \& Economy, P. (2010). Writing Fiction for Dummies. Indianapolis: Wiley Publishing, Inc.

Jabrohim., Sayuti, S.A., \& Anwar, C. (2001). Cara Menulis Kreatif (How to Write Creative). Yogyakarta: Pustaka Pelajar Offset.

Lestari, I. (2013). Pengembangan Bahan Ajar Berbasis Kompetensi: Sesuai Dengan Kurikulum Tingkat Satuan Pendidikan (Development of Competence Based Instructional Materials: In Accordance with Education Unit Level Curriculum). Jakarta: Indeks.

Majid, A. (2008). Perencanaan Pembelajaran Mengembangkan Kompetensi Guru (Learning Planning Develops Master Competencies.). Bandung: PT Remaja Rosdakarya.

Prastowo, A. (2013). Panduan Kreatif Membuat Bahan Ajar Inovatif: Menciptakan Metode Pembelajaran yang Menarik dan Menyenangkan (Creative Guide Creating Innovative Instructional Materials: Creating Interesting and Exciting Learning Methods). Yogyakarta: Diva Press.

Pratiwi, Y., Suherjanto, I., \& Sakti, K.A. (2016). Membaca Estetik Puisi: Dasar Teori dan Model Pelatihan (Reading Aesthetic Poetry: Basic Theory and Training Models). Yogyakarta: Ombak.

Ramet, A. (1997). Creative Writing. Oxford UK: How to Books Ltd.

Richard, J.C. (2002). Curriculum Development in Language Teaching. United States of America: Cambridge University Press.

Sanjaya, W. (2008). Perencanaan dan Desain Sistem Pembelajaran (Planning and Design of Learning System). Jakarta: Kencana Prenada Media Group.

Seoane, C.D.A. \& Rodriguez, J.R. (2014). Characteristics and Properties of the Didactic Materials Developed by Local Governments. Jurnal Orbis Scholae Vol. 8 No. 2 page 23-41.

Sherry, J.F. \& Schouten, J.W. (2002). A Role for Poetry in Consumer Research. Journal of Consumer Research. Vol 29. Halaman 218-234.

Siddiq, M.D., Munawaroh, I., dan Sungkono. (2008). Pengembangan Bahan Pembelajaran SD (Development of Primary School Learning Materials). Jakarta: Departemen Pendidikan Nasional.

Stanton, R. (2007). Teori Fiksi (Fiction Theory). Yogyakarta: Pustaka Pelajar.

Suyitno, I., Susanto, G., Kamal, M., \& Fawzi, A. (2017). Teaching Materials and Techniques Needed by Foreign Students in Learning Bahasa Indonesia. ISLLAC: Journal of Intensive Studies on Language, Literature, Art, and Culture, 1(1), 52-70.

Teeuw, A. (2012). Sastra dan IImu Sastra. (Literature and Literature.)Bandung: Pustaka Jaya.

Ukas, M. (2010). Nature in Poetry of Giovanni Pascoli. London: Routledge. (Online) (http://dx.doi.org/10.1080/00230332.1966.9926214).

Waluyo, H.J. (2010). Pengkajian dan Apresiasi Puisi (Assessment and Appreciation of Poetry). Salatiga: Wydia Sari Press.

Widodo, C.S \& Jasmadi. (2008). Panduan Menyusun Bahan Ajar Berbasis Kompetensi (Guidelines on Competence-Based Instructions). Jakarta: PT Elex Media Komputinda. 